\title{
Constitutional Question: Alternatif Baru Pelindungan Hak Konstitusional Warga Negara Melalui Concrete Review di Indonesia \\ Constitutional Question: New Alternative to Protect Citizen's Constitutional Right From Concrete Review in Indonesia
}

\author{
Xavier Nugraha, Ave Maria Frisa Katherina, Safira Noor Ramadanty, \\ dan Elma Putri Tanbun \\ Fakultas Hukum Universitas Airlangga \\ Jl. Dharmawangsa Dalam Selatan, Airlangga, Gubeng, Surabaya, Jawa Timur 60286 \\ email: xavier.nugraha-2015@fh.unair.ac.id
}

Naskah diterima: 3 Maret 2019

Naskah direvisi: 28 April 2019

Naskah diterbitkan: 1 Juni 2019

\begin{abstract}
The authority of the Constitutional Court in the current regulations in Indonesia still does not fully protect the constitutional rights of the citizens. This is reflected by seeing that the examination that were accommodated only covered the abstract review (there were no concrete cases in the court). This condition causes the absence of legal remedies to resolve the issue of constitutionality of legal norms in the court (concrete review), even though often the issue of constitutionality of laws is precisely found in court proceedings. This research is a dogmatic legal research. The primary legal material usedis the Law of the Constitutional Court, whilst the secondary legal material consists of books, journals, and other relevant sourcesrelated to the issues discussed in this research. Based on this research, it was found that it is necessary to raise a constitutional question so that the Acts that are being examined can be annuled by the Constitutional Court and articles that are considered in contrary to the constitution cannot be used as a basis by the judge to decide related cases that being examined concretely.
\end{abstract}

Keywords: constitutional question; concrete review; Constitutional Court

\begin{abstract}
Abstrak
Wewenang Mahkamah Konstitusi yang ada dalam peraturan perundang-undangan di Indonesia saat ini masih belum melindungi hak-hak konstitusional warga negara secara penuh. Hal ini tercermin dari pengujian yang diakomodasi hanyalah melingkupi abstract review (belum adanya kasus konkrit di pengadilan). Kondisi ini menyebabkan tidak adanya upaya hukum menyelesaikan persoalan konstitusionalitas norma hukum di pengadilan (concrete review), padahal sering kali persoalan konstitusionalitas undang-undang justru ditemukan dari proses di pengadilan. Penelitian ini merupakan penelitian hukum dogmatik. Bahan hukum primer yang digunakan yaitu Undang-Undang Mahkamah Konstitusi, sedangkan bahan hukum sekunder terdiri dari buku, jurnal, dan sumber lain yang relevan dengan masalah yang dibahas dalam penelitian ini. Berdasarkan penelitian ini, ditemukan bahwa perlu diterapkannya constitutional question supaya undang-undang yang diujikan dapat dibatalkan oleh Mahkamah Konstitusi dan pasal yang dinilai bertentangan dengan konstitusi tersebut tidak dapat dijadikan dasar oleh hakim untuk memutus terkait kasus yang diujikan secara konkrit.
\end{abstract}

Kata kunci: constitutional question; concrete review; Mahkamah Konstitusi 


\section{Pendahuluan}

Pembagian kekuasaan untuk menghindari terjadinya kekuasaan yang absolut sering menggunakan konsep trias politica yang didaraskan oleh Montesqieu. Distribusi kekuasaan yang baik diharapkan dapat mewujudkan keseimbangan kekuasaan antara satu lembaga dengan lembaga lain dan saling mengontrol untuk menghindari penyimpangan. ${ }^{1}$ Trias politica adalah suatu ajaran yang mempunyai anggapan bahwa kekuasaan negara terdiri dari tiga macam kekuasaan, yaitu legislatif, eksekutif, dan yudikatif. ${ }^{2}$ Lembaga yudikatif yang merupakan kekuasan kehakiman adalah kekuasaan yang merdeka dalam menyelenggarakan peradilan untuk menegakkan hukum dan keadilan. Pasal 24 ayat (2) Undang-Undang Dasar Negara Republik Indonesia (selanjutnya disebut UUD NRI 1945) ${ }^{3}$ telah menyebutkan secara tegas bahwa kekuasaan kehakiman dilakukan oleh Mahkamah Agung beserta peradilan di bawahnya dan Mahkamah Konstitusi.

Mahkamah Agung dan Mahkamah Konstitusi memiliki wewenang yang berbeda, meskipun keduanya merupakan lembaga yudikatif. Pasal 24A dan Pasal 24C UUD NRI 1945 telah membedakan kewenangan kedua badan peradilan tersebut. Mahkamah Agung berwenang mengadili perkara tingkat kasasi di bawah undang-undang, dan wewenang lain yang diberikan undang-undang. Sedangkan, Mahkamah Konstitusi berwenang mengadili pada tingkat pertama dan terakhir yang putusannya bersifat final untuk menguji undang-undang terhadap Undang-Undang

1 Sunarto, "Prinsip Check and Balances dalam Sistem Ketatanegaraan Indonesia”, Masalah-Masalah Hukum, Vol. 45, No. 2, April 2016, hal. 157.

2 Efi Yulistyowati, Endah Pujiastuti, dan Tri Mulyani, "Penerapan Konsep Trias Politica dalam Sistem Pemerintahan Republik Indonesia: Studi Komparatif atas Undang-Undang Dasar Tahun 1945 Sebelum dan Sesudah Amandemen”, Jurnal Dinamika Sosial Budaya, Vol. 18, No. 2, Desember 2016, hal. 330.

3 Penggunaan frasa UUD NRI 1945 digunakan untuk membedakan dengan UUD 1945 yang merupakan Undang-Undang Dasar sebelum amandemen.
Dasar, memutus sengketa kewenangan lembaga negara yang kewenangannya diberikan konstitusi, serta memutus pembubaran partai politik dan perselisihan hasil pemilu. Dengan kata lain, konstitusi memberikan sebuah lembaga yudikatif, yaitu Mahkamah Konstitusi, bukan hanya sebagai pengawal konstitusi (the guardian of the constitution), ${ }^{4}$ namun juga sebagai pengawal hakhak konsitusional warga negara (the guardian of citizen's constitutional rights) ${ }^{5}$ yang bertugas sebagai pelindung demokrasi, pelindung hak asasi manusia, dan menjamin pelindungan hak-hak konstitusional bagi rakyatnya. ${ }^{6}$

Meskipun Mahkamah Konstitusi mendapat tugas sebagai the guardian of citizen's constitutional rights, namun kewenangan yang dimiliki oleh Mahkamah Konstitusi dalam UUD NRI 1945 hanya dirumuskan dalam rumusan yang sangat singkat dan sepintas saja. Salah satu kewenangan yang berkaitan dengan tugas Mahkamah Konstitusi sebagai the guardian of citizen's constitutional rights, namun hanya diatur secara singkat dalam UUD NRI 1945 adalah terkait pengujian konstitusional (constitutional review). ${ }^{7}$ Berikut bunyi rumusan yang dimaksud, "Mahkamah Konstitusi berwenang mengadili pada tingkat pertama dan terakhir yang putusannya bersifat final untuk menguji undang-undang terhadap Undang-Undang Dasar..."

4 Mei Susanto, "Kewenangan Mahkamah Konstitusi sebagai Negative Budgeter dalam Pengujian UndangUndang Anggaran Pendapatan dan Belanja Negara", Jurnal Konstitusi, Vol. 14, No. 4, Desember 2017, hal. 737.

5 Janedri M.Gaffar, "Peran Mahkamah Konstitusi dalam Perlindungan Hak Asasi Manusia”, Jurnal Konstitusi, Vol. 10, No. 1, Maret 2013, hal. 13.

6 Ibid.

7 Di Indonesia, konteks Pengujian konstitusinal menurut Pasal 24C ayat (1) UUD 1945 hanya ditentukan limitatif, yakni hanya mencakup pengujian terhadap undang-undang saja. Hal ini sangat berbeda dengan negara lain, seperti di Jerman, di mana pengujian tidak hanya dalam produk undang-undang saja, namun dalam semua peraturan perundangan-undangan, lihat Pasal 93 ayat (1) angka 2 dan Pasal 100 ayat (1) Basic Law 1949 (Konstitusi Federal Jerman).

$8 \quad$ Pasal 24C ayat (1) Undang-Undang Dasar 1945. 
Di luar rumusan yang sangat singkat itu, tidak ada petunjuk lain yang diberikan oleh UUD NRI 1945 mengenai ketentuan lebih lanjut mengenai pengujian konstitusional. Dalam Pasal 24C ayat (6) UUD NRI 1945, menyebutkan bahwa pengaturan lebih lanjut mengenai hukum acara dan lain-lain menyangkut Mahkamah Konstitusi akan diatur dengan undang-undang. Dengan demikian, bisa dikatakan, bahwa wewenang Mahkamah Konstitusi dalam menguji undangundang terhadap UUD NRI 1945 hanya dirumuskan secara umum dan tidak langsung dapat dipahami karena UUD sama sekali tidak memberi gambaran apapaun tentang arah pelaksanaannya. ${ }^{9}$

Atas dasar kewenangan delegasi (delegatie van bevogheid) yang diberikan oleh Pasal 24C ayat (6) UUD NRI 1945, maka lahirlah Undang-Undang No. 24 Tahun 2003 tentang Mahkamah Konstitusi, yang kemudian diubah dengan Undang-Undang No. 8 Tahun 2011 (selanjutnya disebut UU MK). Berdasarkan UU MK ini, ditentukan bahwa ruang lingkup pengujian konstitusional di Mahkamah Konstitusi hanya meliputi pengujian abstrak (abstract review). ${ }^{10}$ Dikategorikan sebagai pengujian abstrak karena pada prinsipnya yang diuji adalah norma undang-undang yang bersifat abstrak, bukan norma undang-undang yang sedang atau akan diterapkan dalam kasus konkrit di pengadilan. ${ }^{11}$ Selain itu, pengajuan permohonan oleh Mahkamah Konstitusi itu tidak serta merta menghentikan sementara proses litigasi dari kasus yang bersangkutan.

9 Fajrul Falaakh, "Konstitusi dalam Berbagai Lapisan Makna, Jurnal Konstitusi, Vol. 3, No. 3, September 2006. hal. 17.

10 Hamid Chalid, "Urgensi dan Upaya untuk Implementasi Mekanisme Constitutional Question Melalui Mahkamah Konstitusi RI," dalam Nur Hidayat Sardini dan Gunawan Suswantoro (editor), 60 Tahun Jimly Asshiddiqie Menurut Para Sahabat, Jakarta: Yayasan Pustaka Obor Indonesia, 2016, hal. 361.

11 Pan Mohammad Faiz dan Joshua Collins, "Penambahan Kewenangan Constitutional Question di Mahkamah Konstitusi sebagai Upaya untuk Melindungi Hak-Hak Konstitusional Warga Negara”, Jurnal Konstitusi, Vol. 15, No. 4, Desember 2018. hal. 694.
Seandainya pada suatu saat ketika Mahkamah Konstitusi menerima permohonan pengujian undang-undang dalam kaitannya dengan suatu kasus konkrit di pengadilan, hal tersebut tetap jatuh pada ranah pengujian abstrak, karena secara formal procedural Mahkamah Konstitusi tidak dilengkapi dengan kewenangan menguji suatu kasus konkrit. Hal ini misalnya terlihat dalam Pasal 58 UU MK jo. Pasal 39 Peraturan Mahkamah Konstitusi No. 6 Tahun 2005 tentang Pedoman Beracara Dalam Perkara Pengujian Undang-Undang, yang menyatakan bahwa Putusan Mahkamah Konstitusi tidak berlaku surut atau bersifat prospektif. ${ }^{12}$ Hal tersebut menunjukan bahwa, norma yang dibatalkan tersebut tetap berlaku mengikat rakyat sebelum adanya putusan Mahkamah Konstitusi dan norma tersebut, dapat dijadikan dasar untuk mendakwa seseorang. ${ }^{13}$

Pengujian norma konkrit (concrete norm review) dengan objek permohonan adalah norma undang-undang dalam kaitannya dengan suatu kasus konkrit di pengadilan disebut juga sebagai constitutional question. ${ }^{14}$ Constitutional question adalah mekanisme dalam kerangka pengujian konstitusional di mana hakim-hakim dari pengadilan biasa (pengadilan di luar Mahkamah Konstitusi) dapat mengajukan pertanyaan konstitusional dalam bentuk pengujian undang-undang kepada Mahkamah Konstitusi apabila dalam menangani suatu kasus ia merasa ragu akan konstitusionalitas undang-undang yang akan ia terapkan. ${ }^{15}$ Selanjutnya, manakala constitutional

12 Eddo Febriansyah, "Tinjauan Yuridis Putusan Mahkamah Konstitusi Nomor 46/PUU-VIII/2010 tentang Kedudukan Anak di Luar Nikah yang Diakui dalam Pembagian Warisan”, Unnes Law Jurnal, Vol. 4, No. 1, 2015, hal. 11.

13 Moh. Mahfud MD, "Rambu Pembatas dan Perluasan Kewenangan Mahkamah Konstitusi”, Jurnal Hukum, Vol. 16, No. 4, 2009, hal. 455.

14 Arief Ainul Yaqin, Constitutional Question Kewenangan yang Terlupakan dan Gagasan untuk Melembagakannya di Mahkamah Konstitusi, Jakarta: Sinar Grafika, 2018, hal. 4.

15 Ibid, hal. 3. 
question diajukan, maka proses persidangan atas kasus konkrit yang dimaksud harus dihentikan sementara hingga adanya putusan constitutional question tersebut. ${ }^{16}$

Dari tahun 2009 hingga tahun 2019, Mahkamah Konstitusi telah memutus 1056 perkara konstitusionalitas dari undangundang, ${ }^{17}$ namun tidak jarang persoalan konstitusionalitas tersebut, justru muncul ketika proses litigasi di peradilan. Bahkan, kelemahan atau inkonstitusionalitas dari sebuah undang-undang, memang seringkali baru di sadari pada saat undang-undang itu sedang "dihidupkan" atau diterapkan oleh hakim dalam kasus konkrit. Pada saat seperti itu, justru orang mulai sadar akan inkonstitusionalitas dari sebuah undangundang. Bahkan ada pula permohonan yang baru diajukan oleh pemohon setelah yang bersangkuatan selesai menjalani masa pidananya, di mana ia telah dijatuhi vonis bersalah oleh pengadilan, seperti kasus $\mathrm{R}$. Panji utomo dalam Putusan Mahkamah Konstitusi No. 6/PUU-V/2007. Ironinya, tidak jarang pasal-pasal yang dijadikan dasar untuk menghukum seseorang itu kemudian dibatalkan oleh Mahkamah Konstitusi karena terbukti bertentangan dengan UndangUndang Dasar.

Eggi Sudjana, merupakan salah satu contoh rakyat yang telah dirugikan akan adanya penerapan norma inkonstitusional yang tidak dapat dijangkau atau tidak dapat dicegah kerugiannya oleh Mahkamah Konstitusi dikarenakan belum adanya constitutional question di Indonesia. Majelis Hakim Pengadilan Negeri Jakarta Pusat menghukum Eggi tiga bulan penjara dengan masa percobaan enam bulan karena telah terbukti bersalah dengan memenuhi Pasal 134 jo. Pasal 136 bis KUHP, yaitu pasal penghinaan terhadap presiden. Eggi 16 Ibid.

17 Mahkamah Konstitusi, "Rekapitulasi Perkara Pengujian Undang-undang”, https://mkri.id/index. php?page=web.RekapPUU\& menu=5, diakses tanggal 24 Februari 2019.
Sudjana pun memohon pengujian materiil ke Mahkamah Konstitusi terhadap Pasal 134 KUHP, Pasal 136 bis KUHP, dan Pasal 137 KUHP. Kemudian, amar putusan Mahkamah Konstitusi menyatakan bahwa Pasal 134, Pasal 136, dan Pasal 137 KUHP bertentangan dengan UUD NRI 1945 dan tidak mempunyai kekuatan hukum mengikat. ${ }^{18}$ Putusan tersebut diputus pada hari Senin tanggal 4 Desember 2006. Sedangkan perbuatan yang didakwa menghina presiden, dilakukan Eggi pada tanggal 3 Januari 2006. Namun, putusan Mahkamah Konstitusi yang mengabulkan permohonan Eggi tersebut tidak memiliki pengaruh terhadap vonis Eggi Sudjana.

Putusan Mahkamah Konstitusi yang bersifat ex nunc atau pro futuro yang hanya berlaku ke depan ${ }^{19}$ tersebut, membuat pasal penghinaan presiden yang diputus inkonstitusional berdasarkan Putusan Mahkamah Konstitusi No. 013-022/PUU-IV/2006 tidak memiliki pengaruh terhadap vonis yang dijatuhkan pengadilan terhadap perbuatan yang dilakukan sebelum adanya putusan Mahkamah Konstitusi. Sifat seperti ini pula yang menjadi salah satu pertimbangan Mahkamah Agung menolak peninjauan kembali kasus Eggi Sudjana berdasarkan Putusan Mahkamah Agung No. 153 PK/PID/2010 pada 3 Agustus 2011.

Kasus Eggi Sudjana tersebut merupakan cerminan bahwa kewenangan Mahkamah Konstitusi belum memberikan jaminan pemenuhan hak-hak asasi manusia yang dijamin dalam konstitusi bagi warga negara. Sejatinya, tidak terjaminnya pemenuhan hakhak asasi manusia tersebut juga merupakan pelanggaran terhadap Pasal 28 I ayat (4) dan ayat (5) UUD NRI 1945. Pasal a quo menegaskan bahwa pelindungan, pemajuan, penegakan, dan pemenuhan hak asasi manusia

18 Putusan Mahkamah Konstitusi No. 013-022/PUU. IV/2006, hal. 62.

19 Machmud Aziz, "Pengujian Peraturan Perundangundangan dalam Sistem Peraturan Perundangundangan Indonesia", Jurnal Konstitusi, Vol. 7, No. 5, Oktober 2010, hal. 134. 
adalah tanggung jawab negara yang dijamin dan diatur dalam peraturan perundang-undangan. Tidak adanya upaya hukum bagi warga negara Indonesia untuk menerima jaminan hakhak konstitusional yang rawan dilanggar oleh penguasa adalah sebuah ironi yang terjadi saat ini.

Gustav Radburch menyatakan bahwa hukum dalam pencapaiannya tidak boleh lepas dari keadilan, kepastian, dan kemanfaatan. ${ }^{20}$ Hukum yang memberikan manfaat tentu harus responsif dengan realita yang terjadi dalam masyarakat. Status quo menunjukkan bahwa hukum tidak responsif terhadap realita pelanggaran hak konstitusional warga negara. Sedangkan, perubahan hukum sebagai respon perubahan sosial penting untuk membawa dampak positif bagi penyelesaian masalah dengan mengedepankan nilainilai keadilan. Setelah adanya kasus Eggi Sudjana, status quo masih tetap sama seperti pada saat itu, seolah-olah menutup mata dan menganggap kasus tersebut hanyalah angin lalu dari ketidakmujuran, padahal dalam pertimbangan Putusan No. 013-022/PUU. IV/2006 tersebut dapat terlihat harapan dari Mahkamah Konstitusi agar ke depannya memiliki kewenangan constitutional question. ${ }^{21}$ Adanya realita seperti kasus Egi Sudjana tersebut memperlihatkan adanya urgensi untuk memperluas kewenangan Mahkamah Konstitusi untuk membuka upaya masyarakat dalam menuntut hak konstitusionalnya.

20 Suwardi Sagama, "Analisis Keadilan, Kepastian Hukum dan Kemanfaatan dalam Pengelolaan Lingkungan", Mazahib, Vol. 15, No. 1, Juni 2016, hal 22.

21 Dalam Putusan No. 013-022/PUU-IV/2006, hal. 68, terlihat harapan Mahkamah Konstitusi agar memiliki kewenangan terkait constitutional question. Hal ini terlihat dari kalimat "constitutional question dan constitutional complaint, tidak dimiliki oleh Mahkamah ini - setidak-tidaknya sampai dengan saat ini" dan kalimat "Untuk mengatasi persoalan demikan itulah mahkamah konstitusi di negara lain, di samping diberi kewenangan untuk mengadili perkara pengujian undang-undang (judicial review atau constitutional review), juga diberi kewenangan untuk mengadili perkara-perkara constitutional question dan contitutional complaint".
Tanpa adanya perluasan kewenangan Mahkamah Konstitusi saat ini, rakyat tidak akan dapat memperoleh hak konstitusionalnya secara utuh. Ketika ada vonis yang memutus bersalah seseorang dengan dasar pasal yang inkonstusional sebelum adanya putusan Mahkamah Konstitusi yang menyatakan hal tersebut, maka kesalahan tidak ada pada penerapan hukum para penegak hukum. Kacamata prosedural akan menyatakan hal itu tepat dan tidak melanggar hukum. Namun, penerapan hukuman atas dasar pasal yang inkonstitusional senyatanya bukan merupakan keadilan yang hakiki atau keadilan substantif. Demikian, perluasan kewenangan Mahkamah Konstitusi dalam bentuk constitutional question adalah sebuah urgensi untuk melindungi hak-hak konstitusional rakyat dan mencapai keadilan seutuhnya.

Berdasarkan latar belakang di atas, kewenangan yang dimiliki Mahkamah Konstitusi menarik untuk dikaji dari sisi perlunya penambahan constitutional question untuk memberikan pelindungan secara maksimal terhadap hak konstitusional warga negara. Sehingga, penulis mengangkat rumusan permasalahan sebagai berikut: apa yang dimaksud dengan constitutional question sebagai concrete review Mahkamah Konstitusi? dan bagaimana alternatif penerapan constitutional question di Indonesia?

Penelitian ini bertujuan untuk mengkaji dan menemukan konsep constitutional question sebagai salah satu kewenangan Mahkamah Konstitusi untuk melindungi hak konstitusional warga negara terkait dengan concrete review di Mahkamah Konstitusi Selain itu juga untuk mengetahui alternatif penerapan constitutional question di Indonesia.

Penelitian terkait dengan constitutional question pernah dilakukan oleh Pan Mohamad Faiz dan Josua Satria Collins yang berjudul "Penambahan Kewenangan Constutional Question di Mahkamah Konstitusi sebagai 
Upaya untuk Melindungi Hak-Hak Konstitusional Warga Negara” pada Jurnal Konstitusi Volume 15 Nomor 4, tahun Desember 2018. Pada penelitian tersebut belum dilakukan komparasi pengaturan di negara lain dan belum mengusulkan alternatif pengimplikasian constitusional question di Indonesia, sedangkan dalam penulisan ini tidak hanya membahas mengenai konsep constitutional question, namun juga membahas constitutional question pada negara-negara lain yang sukses mengaplikasikan constitutional question, seperti negara Jerman dan Kroasia dan membahas alternatif mengenai pengaturan constitutional question di Indonesia.

\section{Konsep Constitutional Question}

Terdapat dua isu pokok yang senantiasa menjadi inspirasi perkembangan prinsipprinsip negara hukum, yaitu masalah pembatasan kekuasaan dan pelindungan hak asasi manusia. Kepentingan paling mendasar dari setiap warga negara adalah pelindungan terhadap hak-haknya sebagai manusia. ${ }^{22}$ Negara yang menyatakan dirinya sebagai negara hukum yang menempatkan konstitusi sebagai hukum tertinggi harus mampu menyediakan ruang pelindungan yang maksimal terhadap hak-hak konstitusional warga negaranya.

Salah satu dimensi pelindungan konstitusional adalah pelindungan bagi warga negara dari ancaman penerapan undang-undang yang konstitusionalitasnya masih diragukan atau dipersoalkan. Untuk melindungi hak warga negara tersebut, mekanisme yang dapat dilakukan adalah pengujian konstitusional (constitutional review) melalui mekanisme constitutional question atau pengujian norma konkret.

Secara leksikal, constitutional question berarti persoalan konstitusional atau

22 Achmad Edi Subiyanto, "Perlindungan Hak Konstitusional Melalui Pengaduan Konstitusional", Jurnal Konstitusi, Vol. 8, No. 5, Oktober 2011, hal. 708. pertanyaan konstitusional. ${ }^{23}$ Constitutional question memiliki dua pengertian, yaitu umum dan khusus. Dalam pengertiannya yang umum, constitutional question merujuk pada setiap persoalan-persoalan atau pertanyaanpertanyaan yang berkaitan dengan konstitusi. Sedangkan dalam pengertiannya yang khusus, constitutional question merujuk pada suatu mekanisme pengujian konstitusionalitas undang-undang di mana seorang hakim dari peradilan biasa (ordinary courts) yang sedang mengadili suatu perkara menilai atau raguragu akan konstitusionalitas undang-undang yang berlaku dalam perkara itu. ${ }^{24}$

Sejarah kelahiran constitutional question tidak terlepas dari berdirinya lembaga adjudikasi konstitusi di Austria. Ide membentuk lembaga adjudikasi konstitusi tersebut menjadi hal pertama yang digagas oleh Hans Kelsen setelah berakhirnya Perang Dunia I, yang diikuti oleh runtuhnya kekaisaran Austro-Hungaria dan berdirinya Republik Austria. Di republik yang baru terbentuk ini, Hans Kelsen diangkat menjadi Chancelery yang bertugas menyusun konstitusi dalam rangka pembaruan konstitusi Austria (1919-1920). ${ }^{25}$ Berawal dari hal tersebut, Hans Kelsen mengemukakan gagasannya tentang perlunya Austria memiliki lembaga adjudikasi konstitusi yang terpisah dari sistem peradilan biasa. Menurut Kelsen, penerapan aturanaturan konstitusional di bidang perundangundangan (hirarki perundang-undangan) hanya dapat secara efektif dijamin apabila ada organ di luar badan legislatif yang dipercayakan untuk menguji apakah suatu undang-undang bersifat konstitusional, dan membatalkannya jika menurut pendapat organ ini undangundang tersebut inkonstitusional. Untuk tujuan itu maka perlu dibentuk suatu organ

23 Jazim Hamidi dan Mustafa Lutfi, "Constitutional Question (Antara Realitas Politik dan Implementasi Hukumnya”, Jurnal Konstitusi, Vol. 7, No. 1, Februari 2010, hal. 32

24 Ibid, hal. 33.

25 Ibid, hal. 34. 
khusus semacam pengadilan khusus, yang disebut Mahkamah Konstitusi. ${ }^{26}$ Dengan demikian, terbentuknya Mahkamah Konstitusi adalah untuk menegakkan supremasi konstitusi dengan melaksanakan pengujian konstitusional atau constitutional review.

Pengujian konstitusional merupakan produk sistem pemerintahan modern yang dilandasi oleh gagasan negara hukum (rule of law), pemisahan kekuasaan (separation of powers), dan pelindungan terhadap hak asasi manusia (protection of fundamental rights). ${ }^{27}$ Menurut Herbert Hesmauninger, ${ }^{28}$ pengujian konstitusional yang dilakukan Mahkamah Konstitusi memiliki dua tujuan utama yaitu (a) menjamin berfungsinya sistem demokrasi dalam hubungan saling mempengaruhi antara lembaga eksekutif, legislatif dan yudisial; dan (b) melindungi setiap warga negara dari kemungkinan penyalahgunaan kekuasaan oleh lembaga negara yang merugikan hakhak konstitusional warga negara yang dijamin dalam konstitusi.

Berdasarkan hal tersebut di atas, constitutional review memiliki tujuan salah satunya untuk memberikan pelindungan terhadap hak-hak konstitusional warga negara. Pelindungan terhadap hak-hak konstitusional ini menjadi penting digarisbawahi dalam setiap negara hukum (yang demokratis) yang menempatkan konstitusi sebagai hukum tertinggi, karena tatkala hak-hak tersebut dimasukkan ke dalam konstitusi, berarti telah dijamin dan menjadi bagian dari konstitusi, sehingga mengikat seluruh cabang kekuasaan negara.

Constitutional question sejatinya masuk ke dalam ranah pengujian konstitusional yang berada dalam ruang lingkup kewenangan Mahkamah Konstitusi. Dengan kata lain, pengujian konstitusional adalah genus

26 Arief Ainul Yaqin, Op.Cit, hal. 2.

27 I Dewa Palguna, "Constitutional Queston: Latar Belakang dan Praktik di Negara Lain Serta Kemungkinan Penerapannya di Indonesia”, Jurnal Hukum, Vol. 17, No. 1, Januari 2010, hal. 3.

28 Arief Ainul Yaqin, Op.Cit, hal. 15. sedangkan constitutional question adalah spesiesnya. ${ }^{29}$ Secara garis besar pengujian konstitusional terdiri atas dua mekanisme pengujian yaitu (a) pengujian norma asbtrak (abstract review) dan (b) pengujian norma konkret (concrete review).

Pengujian norma abstrak (abstract review) adalah pengujian terhadap norma hukum secara abstrak yang termuat dalam sebuah undang-undang, artinya undang-undang yang diuji tidak terkait dengan suatu kasus konkret apapun di pengadilan. Pengujian norma abstrak terbagi menjadi a priori abstract review/ preventif preview/constitutionl challenge dan posteriori abstract review. ${ }^{30}$

A priori abstract review adalah pengujian terhadap suatu Rancangan Undang-Undang (RUU) yang telah mendapatkan persetujuan dari parlemen namun belum resmi disahkan dan diundangkan. Sedangkan posteriori abstract review adalah model pengujian yang dilakukan ketika undang-undang yang akan diuji itu telah resmi disahkan dan diundangkan. Model pengujian posteriori abstract review ini banyak diadopsi oleh Mahkamah Konstitusi di seluruh dunia termasuk Indonesia, sementara a priori abstract review merupakan ciri khas dari sistem pengujian konstitusional yang berlaku di Perancis yang kewenangannya dimiliki oleh Conseil Constitutionnel atau Dewan Konstitusi. ${ }^{31}$

Selanjutnya, pengujian norma konkret (concrete review) adalah pengujian terhadap suatu undang-undang yang berkaitan dengan suatu kasus konkret yang sedang berjalan di pengadilan. ${ }^{32}$ Mekanisme pengujian norma konkret inilah yang disebut constitutional question.

Pengujian norma konkret (concrete review) atau constitutional question selalu berawal dari adanya suatu proses litigasi di pengadilan, dimana dalam proses tersebut ditemukan adanya persoalan konstitusionalitas dari suatu norma hukum

29 Ibid, hal. 21.

30 Hamid Chalid, Op.Cit, hal. 364.

31 Arief Ainul Yaqin, Op.Cit, hal. 39.

32 Ibid, hal. 39. 
yang menjadi dasar dari kasus konkret yang dimaksud. ${ }^{33}$ Martin Borowski menggambarkan bahwa dalam mekanisme pengujian norma konkret (constitutional question), manakala hakim dari peradilan biasa sedang memutus sebuah kasus dan dia meyakini bahwa undangundang yang akan dia terapkan dalam kasus tersebut bertentangan dengan konstitusi, maka hakim yang bersangkutan dapat mengajukan pertanyaan konstitusional (constitutional question) kepada Mahkamah Konstitusi. ${ }^{34}$ Oleh karenanya constitutional question juga diistilahkan dengan "the constitutionality of law upon the request of the court". 35

Hakim dari peradilan biasa hanya dapat mengajukan constitutional question ketika hakim tersebut sedang memeriksa dan mengadili perkara. ${ }^{36}$ Oleh karena obyek yang diuji adalah undang-undang dalam kaitannya dengan kasus konkret di pengadilan, hakim peradilan umum tidak dapat mengajukan constitutional question untuk undang-undang yang tidak dipakai dalam perkara yang ditanganinya.

Apabila seorang hakim ingin mengajukan pengujian undang-undang ketika sedang tidak berperkara, maka hakim tersebut mengajukan permohonan constitutional question dengan kedudukan sebagai warga negara Indonesia dan menanggalkan status hakimnya. Tentunya, kedudukan hukum (legal standing) dan hak konstitusional yang dianggap dilanggar terhadap hakim tersebut harus relevan dengan permohonan yang diajukannya. ${ }^{37}$

33 Jimly Asshiddiqie, Model-Model Pengujian Konstitusional di Berbagai Negara, Edisi Kedua, Cet. Pertama, Jakarta: Sinar Grafika, 2010, hal. 50.

34 Martin Borowski, “The Beginnings ofGermany's Federal Constitutional Court”, Journal Ratio Juris, Vol. 16, No. 2, Juni 2003, hal. 156.

35 Firmansyah Arifin dan Juliyus Wardi, ed., Merambah Jalan Pembentukan Mahkamah Konstitusi di Indonesia, Jakarta: Konsorsium Reformasi Hukum Nasional, 2002, hal. 9.

36 Josua Satria C. dan Pan Mohamad F., "Penambahan Kewenangan Constitutional Question di Mahkamah Konstitusi sebagai Upaya untuk Melindungi Hak-Hak Konstitusional Warga Negara”, Jurnal Konstitusi, Vol. 15, No. 4, Desember 2018, hal. 693.

37 Firmansyah Arifin, et.al.,eds., Hukum dan Kuasa Konstitusi, Jakarta: Konsorsium Reformasi Hukum Nasional, 2004, hal. 174.
Pengajuan constitutional question oleh hakim dari peradilan biasa tersebut berakibat pada terhentinya seluruh proses litigasi di peradilan (pending review by ordinary courts) untuk sementara waktu hingga Mahkamah Konstitusi mengeluarkan putusan yang bersifat final dan mengikat. ${ }^{38}$ Adapun ratio legis penghentian sementara persidangan ini sejatinya agar jangan sampai putusan atas kasus konkretnya jatuh terlebih dulu, karena norma hukum yang menjadi dasar dari putusan masih dalam tahap pengujian oleh Mahkamah Konstitusi. Pada akhirnya warga negara akan menjadi pihak yang dirugikan akan adanya penerapan norma yang masih diragukan konstitusionalitasnya. Untuk mencegah hal tersebut, maka norma hukum yang menjadi dasar kasus konkret harus diujikan terlebih dulu kepada Mahkamah Konstitusi.

Perlu dijelaskan bahwa dalam mekanisme constitutional question, Mahkamah Konstitusi hanya menguji persoalan konstitusionalitas undang-undang itu dan bukan memutus kasus konkretnya sendiri. Setelah hakim konstitusi memeriksa dan memutus perkara constitutional question yang diajukan, Mahkamah Konstitusi akan mengembalikan kasus tersebut kepada hakim peradilan umum yang memohon. Selanjutnya, peradilan umum memeriksa perkara tersebut dengan mempertimbangkan pendapat atau putusan yang dikeluarkan oleh Mahkamah Konstitusi. ${ }^{39}$ Jika undang-undang atau ketentuan dari undang-undang yang dimaksud dinyatakan konstitusional oleh Mahkamah Konstitusi, maka pengadilan dapat melanjutkan proses litigasinya. Sebaliknya, jika dinyatakan inkonstitusional maka pengadilan tidak dapat menerapkan undang-undang atau ketentuan undang-undang yang dimaksud. ${ }^{40}$

38 Josua Satria C. Dan Pan Mohamad F., Loc.Cit.

39 Pan Mohamad Faiz, 'A Prospect and Challenges for Adopting ConstitutionalComplaintand Constitutional Question in the Indonesian Constitutional Court", Journal Constitutional Review, Vol. 2, No. 1, Mei 2016, hal. 116.

40 Benny K. Harman, Mempertimbangkan Mahkamah Konstitusi, Jakarta: Kepustakaan Populer Gramedia, 2013, hal. 90. 
Melalui mekanisme ini, hakim peradilan biasa tidak hanya bertugas untuk menerapkan undang-undang dalam peristiwa konkret saja, melainkan juga ikut menegakkan konstitusi dan menjaganya dari segala bentuk pelanggaran yang dilakukan oleh legislatif yang telah mengeluarkan undang-undang yang bertentangan dengan konstitusi. Pada pelaksanaannya, mekanisme constitutional question mampu membangun hubungan dialogis antara Mahkamah Konstitusi (constitutional court) dengan para hakim peradilan umum (ordinary judges) guna mempertahankan supremasi konstitusi (supremacy of the constitution), keadilan administratif (administration of justice), dan pelindungan hak asasi manusia (protection of human right). ${ }^{41}$ Adanya mekanisme ini sebagai bagian dari pengujian konstitusional dapat memaksimalkan penghormatan, pemenuhan dan pelindungan terhadap hak-hak konstitusional warga negara yang telah dijamin dalam konstitusi. Dalam hal ini, constitutional question berperan sebagai upaya preventif untuk mencegah pelanggaran hak-hak konstitusional warga negara akibat diterapkannya norma hukum yang masih diragukan konstitusionalitasnya oleh pengadilan, karena norma hukum yang masih diragukan tersebut tidak akan dan tidak boleh diterapkan oleh pengadilan, melainkan harus diajukan kepada Mahkamah Konstitusi untuk diuji konstitusionalitasnya.

Agar penelitian ini komprehensif, mengingat belum adanya constitutional question di Indonesia, untuk mengetahui seluk beluk pengaturan dan praktik constitutional question, maka penelitian ini melakukan komparasi di negara-negara yang telah mempraktikan dan mengadopsi constitutional question. Ditelaah dari perspektif perbandingan, ada terdapat dua model pengaturan constitutional question. Pertama, kewenangan untuk mengadili adanya constitutional question diatur secara langsung di dalam Konstitusi. Model kedua adalah negara 41 Josua Satria C. Dan Pan Mohamad F., Loc.Cit. yang mengatur kewenangan constitutional question tidak secara langsung di dalam konstitusi, namun hanya berdasarkan undangundang. Pada penelitian ini negara yang dipilih adalah Jerman sebagai negara yang mewakili model pertama. Selain itu Jerman memang paling maju dan sering menjadi percontohan bagi Mahkamah Konstitusi di seluruh dunia. Selain Jerman, negara yang dipilih untuk komparasi dalam penelitian ini adalah Kroasia. Kroasia dipilih karena merupakan negara yang mewakili model kedua, yaitu mengatur kewenangan constitutional question di dalam undang-undang. ${ }^{42}$

\section{A. Jerman}

Jerman merupakan salah satu negara yang juga mengadopsi mekanisme constitutional question dalam sistem pengujian konstitusionalnya. Pengujian konstitusioanal ini dilakukan oleh Mahkamah Konstitusi Jerman yang terbentuk melalui pengesahan Basic Law (Grundgesetz atau Konstitusi Federal Jerman) pada tanggal 23 Mei $1949 .{ }^{43}$

Berdasarkan Pasal 93 Konstitusi Federal Jerman, Mahkamah Konstitusi Jerman memiliki kewenangan yang sangat luas meliputi semua persoalan konstitusional yang ada di Republik Federal Jerman. Hal ini dikarenakan Mahkamah Konstitusi Jerman memiliki kewenangan ekslusif terhadap semua proses peradilan terkait ketaatan terhadap konstitusi. ${ }^{44}$ Salah satu diantara kewenangan tersebut adalah melakukan pengujian konstitusional ${ }^{45}$ yang didalamnya mencakup kewenangan untuk memutus perkara terkait concrete review (constitutional question).

42 Muchamad Ali Safa'at, "Menggagas Constitutional Question di Indonesia", Majalah Konstitusi Berita Mahkamah Konstitusi, Desember 2009, hal. 7.

43 Lothar Determann dan Markus heintzen, "Constitutional Review of Statutes in Germany and the United States Compared", Jurnal UC Hastings Ressearch Paper, No. 299, Agustus 2018, hal. 1.

44 I Dewa Palguna, Op.Cit, hal. 5.

45 Kewenangan pengujian konstitusional oleh Mahkamah Konstitusional Jerman mencakup abstract review, concrete review dan contitutional complaint. (Lihat Lothar Determann dan Markus heintzen, Op.Cit, hal. 4. 
Kewenangan Mahkamah Konstitusi Jerman untuk mengadili perkara constitutional question atau yang dalam bahasa Jeman disebut Konkrete Normenkontrolle $^{46}$ disebutkan secara jelas dalam Pasal 100 Konstitusi Federal Jerman. Secara garis besar, mekanisme constitutional question di Jerman sama dengan mekanisme constitutional question di Austria. Constitutional question diawali dengan permohonan atau pertanyaan konstitusional yang diajukan oleh hakim dari peradilan biasa kepada Mahkamah Konstitusi, manakala hakim yang bersangkutan dalam mengadili perkara ragu-ragu atas konstitusionalitas suatu norma hukum yang akan diterapkan dalam kasus tersebut. Permohonan a quo dapat diajukan oleh hakim baik atas inisiatifnya sendiri atau inisiatif para pihak. ${ }^{47}$

Sejak diajukannya constitutional question maka persidangan harus dihentikan untuk sementara sampai adanya putusan Mahkamah Konstitusi yang bersifat final dan mengikat. ${ }^{48}$ Selanjutnya, permohonan hanya dapat diterima oleh Mahkamah Konstitusi jika hakim yang mengajukan permohonan a quo mampu menjelaskan dan meyakinkan setidak-tidaknya bahwa: (a) putusannya benarbenar bergantung pada norma hukum yang dimohonkan pengujiannya dan (b) kejelasan perihal peraturan mana yang dilanggar oleh norma hukum tersebut. ${ }^{49}$

Mahkamah Konstitusi kemudian akan memeriksa dan memutus permohonan constitutional tersebut. Jika Mahkamah Konstitusi memutus bahwa norma hukum yang diujikan tidak bertentangan dengan konstitusi, maka Mahkamah Konstitusi menyatakan bahwa norma hukum a quo konstitusional dan dapat diterapkan oleh pengadilan. Sebaliknya,

46 Arief Ainul Yaqin, Op.Cit, hal. 18.

47 Pasal 100 ayat (1) Konstitusi Federal Jerman juncto Pasal 80 ayat (1) Undang-Undang Federal tentang Mahkamah Konstitusi Jerman.

48 Pasal 100 ayat (1) Konstitusi Federal Jerman.

49 Pasal 80 ayat (2) Undang-Undang Federal tentang Mahkamah Konstitusi Jerman. jika Mahkamah Konstitusi memutus norma hukum a quo bertentangan dengan konsitusi, maka Mahkamah Konstitusi menyatakan bahwa norma hukum a quo adalah inkonstitusional sehingga tidak dapat diterapkan oleh pengadilan. ${ }^{50}$

Hal menarik dari sistem pengujian konstitusional di Jerman adalah tersedianya mekanisme permohonan ganti rugi/ kompensasi terhadap penundaan persidangan di pengadilan biasa, akibat adanya keharusan untuk menunggu Putusan Mahkamah Konstitusi. Hal ini sebagaimana diatur dalam Pasal 97a - Pasal 97e Undang-Undang Federal tentang Mahkamah Konstitusi Jerman. Apabila proses persidangan di Mahkamah Konstitusi telah berlangsung selama 12 bulan sejak pengajuan, maka warga negara yang merasa dirugikan akibat harus menunggu dapat mengajukan permohonan ganti rugi kepada Mahkamah Konstitusi atau disebut "Formal Complaint Against Judicial Delay". ${ }^{51}$

Selain itu, pengujian konstitusional di Jerman tidak hanya mencakup abstract review dan concrete review tapi juga constitutional complaint. Constitutional complaint memiliki arti bahwa setiap orang termasuk badan hukum (sepanjang menyangkut hak-hak konstitusional yang juga berlaku terhadapnya) dapat mengajukan permohonan kepada Mahkamah Konstitusi Jerman untuk menyatakan suatu undang-undang federal atau undang-undang negara bagian tidak berlaku (void), membatalkan suatu tindakan eksekutif atau administratif atau putusan pengadilan yang lebih rendah, baik pengadilan federal maupun pengadilan negara bagian, dengan alasan adanya pelanggaran terhadap hak-hak konstitusional mereka yang dijamin dalam konstitusi. ${ }^{52}$ Dalam hal ini constitutional complaint berperan sebagai mekanisme kontrol konstitusionalisme yang dapat digunakan

\footnotetext{
50 Arief Ainul Yaqin, Op.Cit, hal. 83.

51 Ibid, hal. 84.

52 I Dewa Palguna, Op.Cit, hal. 10.
} 
oleh warga negara yang bersifat represif, yaitu untuk memulihkan penerapan norma hukum yang bertentangan dengan konstitusi sehingga merugikan warga negara. Sedangkan concrete review (constitutional question) bersifat preventif, yaitu untuk mencegah penerapan norma hukum yang bertentangan dengan konstitusi dan diajukan oleh hakim dalam kaitannya dengan kasus konkret. ${ }^{53}$

Dengan adanya 3 mekanisme tersebut, David P. Currie menyatakan bahwa kehadiran Mahkamah Konstitusi Jerman telah mengantarkan Jerman menjadi negara demokrasi yang stabil dengan pola negara hukum yang mapan bahkan melampaui Amerika Serikat. ${ }^{54} \mathrm{Hal}$ ini terutama jika dikaitkan dengan pelindungan hak asasi manusia, maka pelindungan hak asasi manusia di Jerman melalui Mahkamah Konstitusi Jerman dapat dikatakan nyaris sempurna.

\section{B. Kroasia}

Kroasia merupakan salah satu negara yang mengadopsi mekanisme constitutional question dalam sistem pengujian konstitusional melalui Mahkamah Konstitusi. Berbeda dengan negara-negara sebelumnya yang menjabarkan secara jelas dalam konstitusi-nya kewenangan Mahkamah Konstitusi untuk melakukan pengujian konstitusional yang terdiri atas abstract review dan concrete review, Konstitusi Kroasia (The Constitution of the Republic of Croatia) hanya mengatur bahwa Mahkamah Konstitusi berwenang untuk menguji undangundang terhadap undang-undang dasar (vide Pasal 125 Konstitusi Kroasia).

Kewenangan Mahkamah Konstitusi Kroasia tersebut kemudian dijabarkan lebih lanjut dalam Pasal 35 Undang-Undang tentang Mahkamah Konstitusi Kroasia (The Constitutional Act on the Contitutional Court of the Republic of Croatia) bahwa Mahkamah Konstitusi Kroasia berwenang melakukan 53 Arief Ainul Yaqin, Op.Cit, hal. 85.

54 Hamid Chalid, Op.Cit, hal. 373-374. pengujian konstitusional yang terdiri atas abstract review dan concrete review (constitutional question). Dengan demikian sumber kewenangan Mahkamah Konstitusi Kroasia dalam memutus perkara concrete review tidak bersumber dari konstitusi melainkan dari undang-undang.

Mekanisme constitutional question diawali dengan permohonan atau pertanyaan konstitusional yang diajukan oleh hakim dari peradilan biasa kepada Mahkamah Konstitusi, manakala hakim yang bersangkutan dalam mengadili perkara ragu-ragu (akan konstitusionalitas) atau meyakini bahwa norma hukum yang akan diterapkan dalam kasus tersebut bertentangan dengan konstitusi. ${ }^{55}$ Permohonan a quo dapat diajukan oleh hakim baik atas inisiatifnya sendiri atau inisiatif para pihak.

Sejak diajukannya constitutional question maka persidangan harus dihentikan untuk sementara sampai adanya putusan Mahkamah Konstitusi yang bersifat final dan mengikat. ${ }^{56}$ Selanjutnya, setelah permohonan a quo teregister secara resmi di Mahkamah Konstitusi maka Mahkamah Konstitusi menginformasikan hal tersebut kepada Mahkamah Agung.

Mahkamah Konstitusi kemudian akan memeriksa dan memutus permohonan constitutional tersebut. Jika Mahkamah Konstitusi memutus bahwa norma hukum yang diujikan tidak bertentangan dengan konstitusi, maka Mahkamah Konstitusi menyatakan bahwa norma hukum a quo konstitusional dan dapat diterapkan oleh pengadilan. Sebaliknya, jika Mahkamah Konstitusi memutus norma hukum a quo bertentangan dengan konsitusi, maka Mahkamah Konstitusi menyatakan bahwa norma hukum a quo adalah inkonstitusional sehingga tidak dapat diterapkan oleh pengadilan. ${ }^{57}$

55 Pasal 37 ayat (1) Undang-Undang tentang Mahkamah Konstitusi Kroasia.

56 Ibid.

57 Pasal 55 Undang-Undang tentang Mahkamah Konstitusi Kroasia. 
Jika diperhatikan, sistem pengujian konstitusional oleh Mahkamah Konstitusi di Kroasia serupa dengan sistem pengujian konstitusional oleh Mahkamah Konstitusi di Indonesia. Hal ini dapat dilihat dari konstitusi kita, yaitu UUDNRI 1945 khususnya Pasal24C ayat (1) yang hanya menguraikan kewenangan Mahkamah Konstitusi untuk menguji undangundang terhadap undang-undang dasar. Sementara jenis pengujiannya (abstract review/ concrete review) tidak diuraikan. ${ }^{58}$

Selain itu, mekanisme abstract review di Kroasia dan Indonesia adalah posteriori abstract review, yaitu pengujian terhadap undangundang yang telah disahkan dan diundangkan. Abstract review ini dapat diakses oleh semua pihak, baik organ-organ negara maupun perorangan sehingga memberikan sarana bagi warga negara untuk memperoleh keadilan dan kepastian hukum. Berbeda dengan abstact review di Austria dan Jerman yang hanya dapat diakses oleh organ-organ negara tertentu.

\section{Alternatif Pengaturan Constitutional Question sebagai salah satu Kewenangan Mahkamah Konstitusi di Indonesia}

Menurut Mauro Cappeleti, secara garis besar terdapat 2 (dua) model lembaga pengujian konstitusional di dunia, yaitu model decentralized judicial review dan centralized judicial review. ${ }^{59}$ Model pertama, decentralized judicial review adalah model yang meletakkan kewenangan pengujian konstitusional itu secara tersebar kepada Mahkamah Agung atau supreme court dan badan peradilan di bawahnya. ${ }^{60}$ Ciri utama dari model yang ini adalah, pengujian konstitusional hanya dapat dilakukan apabila terkait dengan suatu kasus konkrit di pengadilan (incorporated wuth 58 Arief Ainul Yaqin, Op.Cit, hal. 112.

59 Paolo Passaglia, "Making a Centralized System of Judicial Review Coexist with Decentralized Guardians of the Constitution: The Italian Way", Italian Law Journal, Vol. 2, April 2016, hal. 410.

60 Hamid Chalid, "Dualism of Judicial Review", Indonesia Law Review, Vol. 7, No. 3, September-Desember 2017, hal. 375. (selanjutnya disebut Hamid Chalid II) factual case) dan pengujiannya juga dilakukan oleh hakim yang sedang menangani kasus tersebut. ${ }^{61}$ Dapat dilihat bahwa, dalam model seperti ini pengujian konstitusional dilakukan secara bersamaan dan tidak terpisahkan dengan penyelesaian kasus konkritnya. Dengan demikian mekanisme yang dikenal di negara yang menganut decentralized judicial review hanyalah pengujian norma konkrit. Pelopor model ini adalah negara Amerika Serikat, sehingga sering kali disebut sebagai American Model. ${ }^{62}$

Model kedua, centralized judicial review adalah model yang meletakkan kewenangan pengujian konstitusional itu secara terpusat dengan cara membentuk lembaga adjudikasi konstitusional atau biasa disebut sebagai Mahkamah Konstitusi sebagai organ khusus yang bertugas melakukan pengujian konstitusional. Pelopor model ini adalah Austria. Austria adalah pelopor adanya pengujian konsitusional melalui pembentukan lembaga adjudikasi konstitusional yang terpisah dan berdiri di luar Mahkamah Agung. ${ }^{63}$ Meskipun model yang kedua ini munculnya lebih lama dari pada model yang pertama, namun model yang kedua ini lebih banyak dipakai oleh negara-negara di dunia termasuk Indonesia. Dianutnya model centralized judicial review di Indonesia, dapat terlihat dari posisi Mahkamah Konstitusi yang berbeda dengan Mahkamah Agung, sesuai dengan Pasal 24 UUD NRI 1945, dimana Mahkamah Agung menjalankan tugas untuk judicial review on the legality of law, sementara Mahkamah Konstitusi menjalankan tugas untuk judicial review on the constitutionality of law. ${ }^{64}$

Umumnya di negara-negara yang menganut model centralized judicial review 61 Ibid.

62 Paolo Passaglia, Loc.Cit.

63 Mauro Cappelleti, The Judicial Process in Comparative Perspective, Oxford: Clarendon Press, 1989, hal. 133135.

64 Nurul Qomar, "Kewenangan Judicial Review Mahkamah Konstitusi”, Jurnal Konstitusi, Vol. 1, 2012, hal. 8. 
seperti Austria, Jerman, Spanyol, Italia, Rusia, Thailand, dan sebagainya, pengujian konstitusional di negara tersebut terdiri atas 2 (dua) pengujian, yakni pengujian norma secara abstrak (abstract review) dan pengujian norma secara konkrit (concrete review) atau dikenal sebagai constitutional question. ${ }^{65}$ Bahkan dalam kasus Jerman dan Austria (dan juga mayoritas negara-negara Eropa lainnya), mekanisme concrete review atau constitutional question inilah yang justru lebih penting dan mendominasi praktik pengujian konstitusional di sana. Hal ini dapat terlihat, misalnya dari pendapat Gabriele Kucsko-Stadlmayer yang menyebutkan bahwa "However, abstract review is a very small part of the Court's docket (around 3 percent). Concrete review has much more practical importance" (Bagaimana pun, pengujian norma abstrak hanyalah sebagaian kecil saja dari total perkara yang masuk dan ditangani oleh Mahkamah Konstitusi Austria. Pengujian norma konkritlah yang justru lebih penting dan lebih sering dipraktikkan). ${ }^{66}$

Meskipun pengujian norma secara konkrit (concrete review) di negara lain yang menerapkan model centralized judicial review memiliki peranan yang penting, namun ternyata hal tersebut tidak diatur di Indonesia. Jika di negara lain, umumnya ada 2 (dua) model pengaturan constitutional question, yaitu diatur secara langsung di dalam Konstitusi (konsep ini dianut di Austria, Jerman, Rusia, Spanyol, Korea) ataupun diatur dalam undangundang terkait penjabaran kewenangan hakim Mahkamah Konstitusi di negara tersebut (konsep ini dianut di Kroasia, Belarusia, dan Georgia). ${ }^{67}$ Namun di Indonesia, baik di dalam konstitusi ataupun dalam UU MK, tidak dapat ditemukan sama sekali pengaturan mengenai constitutional question. Dalam rangka melengkapi Mahkamah Konstitusi

65 Martin Borowski, Op.Cit, hal. 156.

66 Gabriele Kucsko-Stadlmayer, "Constitutional Review in Austria: Traditions and New Developments," dalam Arief Ainul Yaqin, Op.Cit, hal. 14.

67 Arief Ainul Yaqin, Op.Cit, hal. 50. di Indonesia, agar tidak hanya memberikan pelindungan melalui pengujian asbtrak, namun juga pengujian konkrit agar dapat memberikan pelindungan secara holistik terkait hak-hak konstitusional warga negara, maka Mahkamah Konstitusi harus memiliki kewenangan constitutional question agar dapat menjadi guardian of citizen's constitutional rights yang komplit.

Sciere leges non hoc est verba corum tenere, sed vim nac potestaem, meskipun peraturan tertulis secara jelas, haruslah ditafsirkan menurut pembuat peraturan tersebut. ${ }^{68}$ Jika kita ingin melihat kehendak dari pembuat UUD NRI 1945, maka kita harus melihat dalam naskah komperhensif UUD NRI 1945 yang merupakan hasil perdebatan terkait substansi UUD NRI 1945. Dalam naskah komprehensif tersebut, sejatinya ide memasukkan constitutional question ini sudah ada. Usulan tersebit disampaikan oleh Fraksi Utusan Golongan. Berikut petikan usulan tersebut:

"Mahkamah Konstitusi mempunyai kewenangan-kewenangan sebagai berikut:

1. menguji undang-undang atas permintaan pengadilan;

2. mengadili pembubaran partai politik;

3. mengadili persengketaan antara instansi pemerintah daerah dan antara pemerintah daerah dengan pemerintah pusat;

4. mengadili adanya suatu pertentangan undang-undang."

Dari rumusan tersebut, dapat dilihat bahwa kewenangan MK untuk mengadili perkaraperkara konkrit atau constitutional question ini sejatinya, sudah ada dalam perdebatan rumusan kewenangan Mahkamah Konstitusi, sehingga usulan mengenai constitutional question ini bukanlah hal yang baru. Dalam rangka memberikan kewenangan constitutional

68 Agus Yudha Hermoko, Hukum Perjanjian: Asas Proporsionalitas dalam Kontrak Komersial, Jakarta: Prenadamedia Group, 2014, hal. 231. 
question atau pengujian abstrak terhadap hakim Mahkamah Konstitusi di Indonesia, dapat dilakukan melalui amandemen UUD NRI 1945 (seperti negara Jerman yang memberikan kewenangan constitutional question kepada hakim Mahkamah Konstitusi melalui konstitusinya) ataupun melalui pengaturan lewat UU MK (seperti negara Kroasia). Sesuai Pasal 37 UUD NRI 1945, memang tidak menutup kemungkinan UUD NRI 1945 untuk diubah, namun hal tersebut akan sangat sulit dilakukan. Kesulitan tersebut dapat dilihat dari dua sisi, yaitu politik dan prosedural. Secara politik, kesulitan tersebut dapat dilihat dari calon anggota Majelis Permusyawaratan Rakyat (MPR) dari utusan golongan ditentukan oleh internal golongan masyarakat itu sendiri. ${ }^{69}$ Sehingga secara politik, menyatukan pandangan politik dari kepentingan politik yang berbeda-beda tentu tidak mudah.

Syarat kedua, terkait prosedural untuk melakukan amandemen pun tidak mudah, sebab ada ketentuan Pasal 37 ayat (3) UUD NRI 1945 yang menyatakan bahwa perlunya kehadiran setidaknya sebanyak 2/3 dari jumlah anggota MPR. Hambatan secara prosedural dan politik tersebut yang merupakan kesulitan dari berhasilnya amandemen UUD NRI 1945. Hal ini menunjukan betapa sulit melakukan amandemen UUD NRI 1945. Dalam rangka sulitnya melakukan amandemen UUD NRI 1945, maka mekanisme lain yang dapat digunakan untuk menambahkan kewenangan pengujian konkrit terhadap Mahkamah Konstitusi, dapat diatur melalui UU MK, sesuai dengan Pasal 24C ayat (6) UUD NRI 1945. Jika kita melihat pada teori norma berjenjang/Stufenbautheorie dari Hans Kelsen yang menjelaskan bahwa aturan yang dibuat harus bersumber dari aturan di atasnya, ${ }^{70}$ maka

69 Widayati, "Rekonstruksi Kelembagaan MPR”, Prosiding Seminar Nasional, Pengembangan Epistimologi Ilmu Hukum, Universitas Muhammadiyah Surakarta, April 2015, hal. 210.

70 Muhtadi, "Penerapan Teori Hans Kelsen Dalam Tertib Hukum Indonesia”, Fiat Justitia Jurnal Ilmu Hukum, Vol. 5, September 2012, hal. 295. dapat kita lihat bahwa sejatinya kewenangan constitutional question yang diatur nantinya di UU MK tersebut, sejatinya bisa bersumber dari Pasal 24 C ayat (1) UUD NRI 1945. Pasal 24C UUD NRI 1945 memang merupakan norma tertutup yang berarti bahwa kewenangan tersebut bersifat limitatif. ${ }^{71}$

Sejatinya, constitutional question secara eksplisit memang tidak termasuk dalam salah satu kewenangan Mahkamah Konstitusi yang ditentukan secara limitatif oleh UUD NRI $1945 .{ }^{72}$ Namun, mendasarkan pada penafsiran ekstensif sejatinya constitutional question tidak bertentangan dengan norma kewenangan pengujian undang-undang terhadap UUD NRI 1945 oleh Mahkamah Konstitusi. Hal ini dapat terlihat dari rumusan Pasal $24 \mathrm{C}$ ayat (1) UUD NRI 1945 yang berbunyi: "Mahkamah Konstitusi... berwenang untuk menguji undang-undang terhadap Undang-Undang Dasar", rumusan tersebut bersifat umum dan oleh karenanya pembentuk UUD NRI 1945 memang mendelegasikan pengaturan lebih lanjut dalam undang-undang sesuai Pasal 24C ayat (6) UUD NRI 1945. Sehingga pengaturan constitutional question dalam revisi UU MK, dapat dikatakan tidak bertentangan dengan UUD NRI 1945. Hal ini sejatinya mirip dengan pengaturan constitutional question di Kroatia. Ilustrasinya seperti terlihat pada Gambar 1.

Setelah mengetahui bahwa pengaturan terkait constitutional question dapat diatur dalam level UU MK, maka yang berikutnya harus dipikirkan adalah terkait mekanisme atau prosedur terkait constitutional question. Secara garis besar prosedur constitutional question/concrete review yang kelak akan diatur dalam UU MK adalah sebagai berikut: ${ }^{73}$

71 Zaka Firma Aditya, "Kewenangan Mahkamah Konstitusi dalam Menyelesaikan perkara Constitutional Complaint berdasarkan Undang-Undang Dasar Tahun 1945", Unnes Law Journal, Vol. 3, No. 1, Juni 2014, hal. 46.

72 Hamdan Zoelva, "Constitutional Complaint dan Constitutional Question dan Perlindungan Hak-Hak Konstitusional Warga Negara", Jurnal Media Hukum, Vol. 19, No. 1, Juni 2012, hal. 153-154.

73 Arief Ainul Yaqin, Op.Cit, hal. 209-210. 

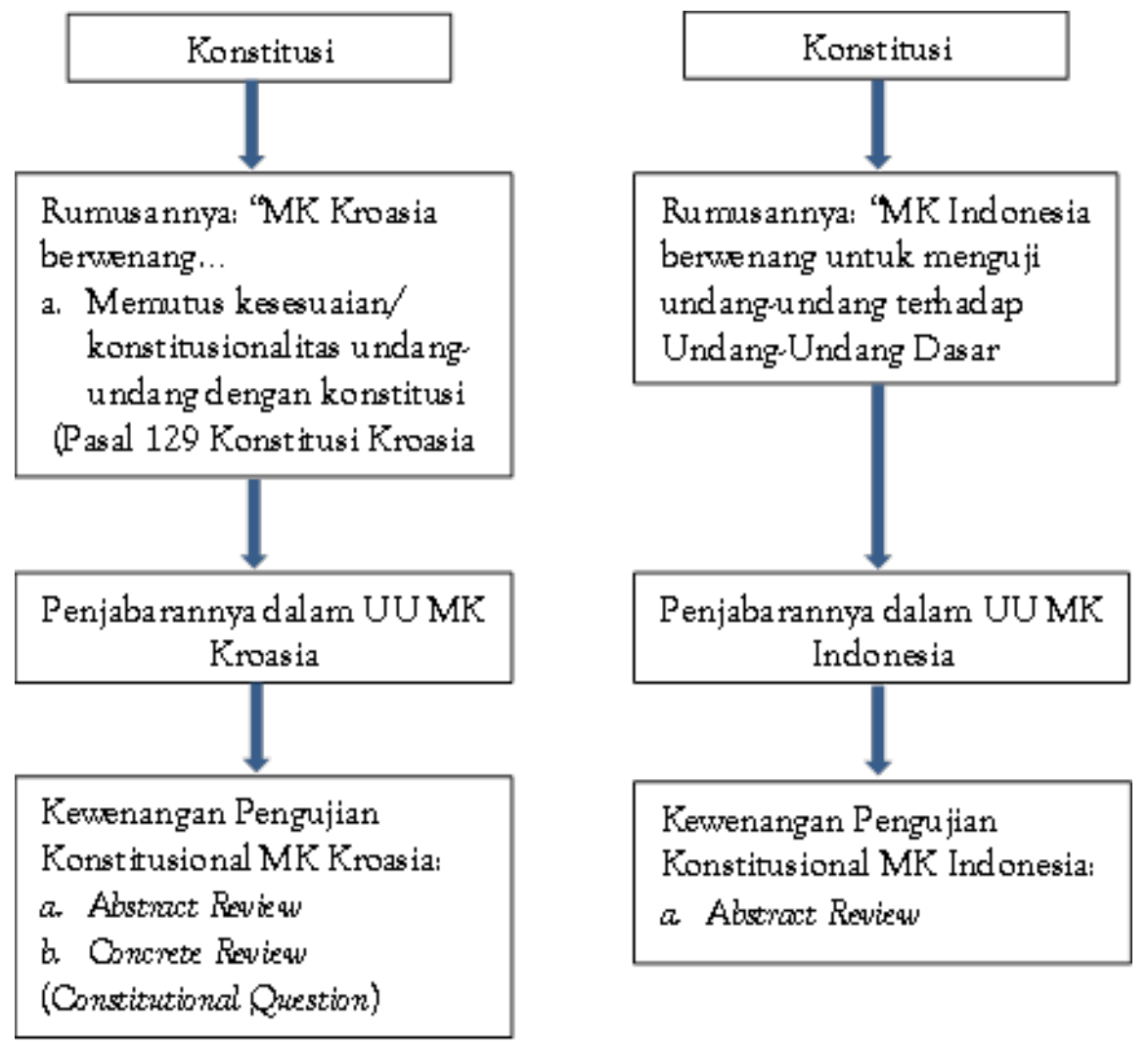

Gambar 1. Perbandingan Rumusan Pengaturan Pengujian Konstitusional di dalam Konstitusi Kroasia dan Konstitusi Indonesia serta Penjabarannya Lebih Lanjut di Dalam UU MK di Indonesia dan Kroasia.

1. Permohonan "pertanyaan konstitusional" diajukan secara langsung oleh hakim dari pengadilan biasa (Pengadilan selain Mahkamah Konstitusi) ${ }^{74}$ kepadaMahkamah Konstitusi bilamana dalam mengadili suatu perkara konkrit hakim menemukan adanya dugaan inkonstitusionalitas dari suatu norma undang-undang yang akan ia terapkan dalam kasus konkrit yang dimaksud;

2. Permohonan itu diajukan oleh hakim, ${ }^{75}$

74 Dalam pasal 51 UU MK tidak dijelaskan mengenai legal standing hakim, nantinya melalui revisi UU MK akan ditambahi secara eksplisit terkait hakim yang memeriksa perkara agar memiliki legal standing yang jelas agar dapat mengajukan "pertanyaan konstitusional".

75 Umumnya terdapat 2 (dua) jenis mekanisme pengajuan constitutional question. Pertama diajukan oleh hakim di semua tingkat, seperti negara Angola, Austria, Jerman, Latvia, dsb. Kedua, pengujian hanya dilakukan oleh supreme court, seperti Belarus, Georgia, dsb. Penulis berpendapat bahwa dalam rangka menerapkan constitutional question di Indonesia, maka dapat diajukan oleh hakim di pengadilan semua tingkat. Hal ini didasarkan jika constitutional question baik atas inisiatifnya sendiri, atapun inisiatif para pihak; ${ }^{76}$

3. Untuk dapat diterimanya permohonan itu oleh Mahkamah Konstitusi, maka hakim yang mengajukan permohonan "pertanyaan konstitusional" harus menjelaskan dan

hanya dapat diajukan oleh Makahamah Agung sebagai supreme court di Indonesia, maka akan bertentangan dengan prinsip Justitiae non est neganda, non differenda, yang artinya keadilan tidak boleh disangkal dan ditunda, penundaan terhadap keadilan adalah bentuk ketidakadilan itu sendiri, sehingga para pihak harus sesegera mungkin mendapat keadilan dalam rangka mendapat perlindungan akan hak konstitusionalnya selebihnya (Moh. Mahfud MD., et al., Constitutional Question: Alternatif Baru Pencari Keadilan Konstitusional, Malang: Universitas Brawijaya Press, 2010, hal. 69).

76 Permohonan pertanyaan konstitusional ini secara formal prosedural memang diajukan oleh hakim pengadilan, akan tetapi inisiatif untuk mengajukan dapat dari pihak yang merasa dirugikan hak-hak konstitusionalnya. Untuk berjalannya prosedur ini harus diatur lewat ketentuan teknis lebih lanjut, misal: melalui Peraturan Makahamah Agung, seperti di Korea Selatan, (Jimly Ashidiqie dan Ahmad Syahrizal, Peradilan Konstitusi di 10 negara, Jakarta: Sinar Grafika, 2012, hal. 240-243). 
meyakinkan setidaknya 2 (dua) hal kepada Mahkamah Konstitusi, yaitu:

a) Putusannya benar-benar bergantung pada norma undang-undang yang dimohonkan pengujiannya itu; dan

b) Kejelasan perihal ketentuan konstitusi yang dilanggar oleh norma undangundang yang dimohonkan pengujiannya.

4. Sejak diajukannya "pertanyaan konstitusional" kepada Mahkamah Konstitusi maka persidangan atas kasus konkritnya harus diberhentikan sementara (ditunda) oleh pengadilan; ${ }^{77}$

5. Dalam proses pengujiannya, Mahkamah Konstitusi hanya memeriksa konstitusionalitas undang-undang, bukan memutus kasus konkretnya, sebab Mahkamah Konstitusi tidak memiliki wewenang untuk memeriksa dan memutus kasus-kasus konkret;

6. Jika Mahkamah Konstitusi memutus bahwa norma undang-undang yang diuji olehnya itu tidak bertentangan dengan Konstitusi (konstitusional), maka pengadilan dapat menerapkan norma undang-undang yang dimaksud;

7. Jika Mahkamah Konstitusi memutus bahwa norma undang-undang yang diuji olehnya itu bertentangan dengan Konstitusi (inkonstitusional), maka pengadilan tidak dapat menerapkan norma undang-undang yang dimaksud;

8. Meski permohonan pertanyaan konstitusional ini berasal dari suatu kasus konkret yang sedang berjalan di pengadilan, akan tetapi Putusan Mahkamah Konstitusi dalam perkara tersebut tetaplah mengikat umum (erga omnes).

Hal esensial lainnya yang juga harus diperhatikan dan dipikirkan dalam rangka mewujudkan ide pelembagaan constitutional

77 Sesuai dengan Putusan Mahkamah Konstitusi No. 93/ PUU-XV/2017, bahwa pengujian UU di Mahkamah Konstitusi akan menghentikan sementara pengujian bahkan di tingkat Mahkamah Agung, sehingga adalah hal yang logis ketika constitutional question diajukan, maka perkara dihentikan sementara, sampai ada putusan Mahkamah Konstitusi terkait constitutional question tersebut. question agar tidak hanya dalam tataran abstraksi, namun juga dapat diimplementasikan secara nyata adalah terkait konsekuensi penundaan persidangan atas kasus konkret yang menjadi asal muasal timbulnya pertanyaan konstitusional yang diajukan oleh Mahkamah Konstitusi. Sebagaimana telah dijelaskan dalam mekanisme constitutional question, bahwa ketika diajukan constitutional question, maka pemeriksaan terhadap kasus konkritnya di pengadilan harus diberhentikan sementara sampai selesai proses constitutional question di Mahkamah Konstitusi. Sebab Putusan Mahkamah Konstitusi tersebut yang nantinya akan menjadi dasar bagi pengadilan yang bersangkutan untuk menerapkan atau tidak menerapkan norma dalam aturan tersebut.

Masalah yang timbul adalah terkait dengan interval penyelesaian kasus di pengadilan. Dalam Pasal 4 ayat (2) Undang-Undang No. 48 Tahun 2009 tentang Kekuasaan Kehakiman yang menggantikan Undang-Undang No. 35 tahun 1999 tentang Perubahan atas UndangUndang Nomor 14 Tahun 1970, dijelaskan bahwa peradilan membantu pencari keadilan dan berusaha mengatasi segala hambatan dan rintangan untuk dapat tercapainya peradilan yang sederhana, cepat dan biaya ringan. Dalam rangka melaksanakan aturan tersebut, Mahkamah Agung menetapkan batas waktu penyelesaian perkara di pengadilan.

Penetapan limitasi penyelesaian putusan oleh Mahkamah Agung ini, diharapkan agar keadilan bagi masyarakat dapat segera diberikan dan dapat segera memberikan kepastian hukum bagi masyarakat. Aturan tentang limitasi waktu penyelesaian perkara di pengadilan ini diatur dalam 2 (dua) peraturan, yaitu melalui Surat Edaran Mahkamah Agung No. 2 Tahun 2014 tentang Penyelesaian Perkara di Pengadilan Tingkat Pertama dan Tingkat Banding dan Keputusan Ketua Mahkamah Agung No. 214/KMA/SK/ 
XII/2014 tentang Jangka Waktu Menangani Perkara Pada Mahkamah Agung.

Pada Surat Edaran Mahkamah Agung No. 2 Tahun 2014, dijelaskan bahwa lamanya proses di pengadilan tingkat pertama adalah 5 (lima) bulan, sedangkan di pengadilan tingkat banding adalah 3 (tiga) bulan. Ketentuan tersebut berlaku terhadap semua perkara di semua pengadilan di bawah Mahkamah Agung, kecuali perkara-perkara yang oleh peraturan perundang-undangan telah ditetapkan batas waktu penyelesaiannya. ${ }^{78}$ Pada Keputusan Ketua Mahkamah Agung No.214/KMA/SK/XII/2014, dijelaskan bahwa batas waktu penyelesaian perkara di tingkat kasasi dan peninjauan kembali adalah 250 hari. Ketentuan tersebut berlaku terhadap semua perkara di semua pengadilan di bawah Mahkamah Agung, kecuali perkaraperkara yang oleh peraturan perundangundangan telah ditetapkan batas waktu penyelesaiannya. ${ }^{79}$

Berdasarkan urian di atas, dapat dilihat bahwa seolah terjadi potensi masalah antara penerapan constitutional question dengan pengaturan interval waktu penyelesaian perkara yang telah ditetapkan. Di satu sisi tidak mungkin dalam menerapkan constitutional question perkara tidak dihentikan, tetapi di sisi lain, tidak mungkin interval waktu penyelesaian perkara akan dihapuskan. Dalam

78 Misal Pada Tindak Pidana Pemilu, pada Pasal 263 Undang-Undang No. 8 Tahun 2012 tentang Pemilihan Umum Anggota dewan Perwakilan Rakyat, Dewan Perwakilan Daerah, dan Dewan Perwakilan Rakyat Daerah dijelaskan bahwa batas waktu penyelesaian tingkat pertama adalah 7 hari, sedangkan banding adalah 7 hari, selain itu tindak pidana korupsi, pada Pasal 29 Undang-Undang No. 46 Tahun 2009 tentang Pengadilan Tindak Pidana Korupsi (UndangUndang No. 46 Tahun 2009), dijelaskan bahwa waktu penyelesaian tingkat pertama adalah 120 hari, sementara tingkat banding dalam Pasal 30 UndangUndang No. 46 Tahun 2009 adalah 60 hari.

79 Misalnya pada Tindak Pidana korupsi, sesuai Pasal 31 Undang-Undang No. 46 Tahun 2009, dijelaskan bahwa waktu penyelesaian tingkat kasasi adalah 120 hari, sementara lama penyelesaian peninjauan kembali dalam Pasal 32 Undang-Undang No. 46 Tahun 2009 adalah 60 hari. rangka mengaasi masalah tersebut, maka ada 2 (dua) hal yang harus diatur. Pertama, adalah terkait penghentian interval penyelesaian di pengadilan. Selama pengajuan constitutional question, maka akan menghentikan perhitungan limitasi waktu penyelesaian perkara konkritnya sampai adanya putusan Mahkamah Konstitusi. Setelah Mahkamah Konstitusi mengeluarkan putusan akan constitutional question tersebut, barulah interval waktu penyelesaian perkara tersebut kembali dilanjutkan. Dengan adanya pengaturan ini, tidak akan mengganggu interval waktu penyelesaian perkara yang diatur dalam Surat Edaran Mahkamah Agung No. 2 Tahun 2014 dan Keputusan Ketua Mahkamah Agung No. 214/KMA/SK/XII/2014. Kedua, adalah terkait penetapan batas waktu pengujian constitutional question di Mahkamah Konstitusi.

Hal ini penting, karena di beberapa negara penyelesaian constitutional question bahkan bisa memakan waktu cukup lama. Penetapan batas waktu pengujian constitutional question ini penting untuk diatur agar perkara tidak menjadi terkatung-katung, dan peradilan tersebut tetap menjalankan asas peradilan, cepat sederhana, dan biaya ringan.

\section{Penutup}

\section{A. Simpulan}

Penghormatan, pemenuhan dan pelindungan terhadap hak-hak konstitusional warga negara merupakan sebuah keharusan mutlak yang tidak dapat ditawar bagi negara hukum yang menempatkan konstitusi sebagai hukum tertinggi. Salah satu upaya untuk mewujudkan hal tersebut adalah dengan mekanisme constitutional question sebagai bagian dari pengujian konstitusional yang dilakukan oleh Mahkamah Konstitusi. Dalam hal ini, constitutional question berperan sebagai upaya preventif untuk mencegah pelanggaran hak-hak konstitusional warga negara akibat diterapkannya norma hukum yang masih diragukan konstitusionalitasnya 
oleh pengadilan, karena norma hukum yang masih diragukan tersebut tidak akan dan tidak boleh diterapkan oleh pengadilan, melainkan harus diajukan kepada Mahkamah Konstitusi untuk diuji konstitusionalitasnya. Pada kenyataannya, Indonesia hingga saat ini belum mengadopsi constitutional question dalam sistem pengujian konstitusionalnya. Hal ini dapat dilihat dari belum adanya pengaturan mengenai mekanisme constitutional question baik dalam konstitusi maupun UU MK. Dengan demikian pengujian konstitusional di Indonesia hanya mencakup abstract review saja.

Jika melihat perbandingan dengan praktik constitutional question di Kroasia, konstruksi pemikiran dan substansi constitutional question sangat memungkinkan untuk diadopsi di Indonesia. Pengadopsian tersebut dapat melalui penambahan kewenangan Mahkamah Konstitusi untuk melakukan pengujian konkrit di dalam UU MK, sehingga kewenangan Mahkamah Konstitusi diperluas mencakup abstract review dan concrete review. Dengan adanya mekanisme constitutional question melaui concrete review sebagai bagian dari pengujian konstitusional dapat memaksimalkan peran Mahkamah Konstitusi sebagai guardian of citizen's constitutional rights, karena tidak hanya memberikan pelindungan melalui pengujian abstrak saja, namun juga pengujian konkrit agar dapat memberikan pelindungan secara holistik terhadap hakhak konstitusional warga negara. Konsep dari constitutional question sendiri adalah concrete review yang dipicu oleh adanya kasus di pengadilan mengenai konstitusionalitas suatu norma hukum yang menjadi dasar kasus tersebut, sehingga sebelum memutus hakim dapat menanyakan konstitusionalitas sebuah norma hukum kepada Mahkamah Konstitusi sebelum menjatuhkan putusan atas dasar norma hukum yang diduga inkonstitusional.

\section{B. Saran}

Adapun penambahan kewenangan Mahkamah Konstitusi untuk melakukan concrete review di Indonesia harus diatur dengan jelas, mulai dari prosedur hingga batas waktunya. Pengaturan prosedur dan batas waktu pengujian constitutional question ini menjadi penting untuk menciptakan kepastian hukum dan perkara tidak menjadi terkatungkatung, sehingga peradilan tersebut tetap menjalankan asas peradilan, cepat sederhana, dan biaya ringan.

\section{Daftar Pustaka}

\section{Jurnal}

Aditya, Zaka Firma. "Kewenangan Mahkamah Konstitusi dalam Menyelesaikan perkara Constitutional Complaint berdasarkan Undang-Undang Dasar Tahun 1945". Unnes Law Journal. Vol. 3. No. 1. Juni 2014.

Aziz, Machmud. "Pengujian Peraturan Perundang-undangan dalam Sistem Peraturan Perundang-undangan Indonesia. Jurnal Konstitusi. Vol. 7. No.5. Oktober 2010.

Borowski, Martin. "The Beginnings of Germany's Federal Constitutional Court”. Journal Ratio Juris. Vol. 16. No. 2. Juni 2003.

Chalid, Hamid. "Dualism of Judicial Review". Indonesia Law Review. Vol. 7. No. 3. September-Desember 2017.

Determan, Lothar dan Markus heintzen. "Constitutional Review of Statutes in Germany and the United States Compared". Jurnal UC Hastings Ressearch Paper. No. 299. Agustus 2018.

Falaakh, Fajrul. "Konstitusi dalam Berbagai Lapisan Makna. Jurnal Konstitusi. Vol. 3. No. 3. September 2006. 
Faiz, Pan Mohamad. "A Prospect and Challenges for Adopting Constitutional Complaint and Constitutional Question in the Indonesian Constitutional Court". Journal Constitutional Review. Vol. 2. No. 1. Mei 2016.

Faiz, Pan Mohammad dan Joshua Collins. "Penambahan Kewenangan Constitutional Question di Mahkamah Konstitusi sebagai Upaya untuk Melindungi HakHak Konstitusional Warga Negara”. Jurnal Konstitusi. Vol. 15. No. 4. Desember 2018.

Febriansyah, Eddo. "Tinjauan Yuridis Putusan Mahkamah Konstitusi Nomor 46/PUU. VIII/2010 tentang Kedudukan Anak di Luar Nikah yang Diakui dalam Pembagian Warisan”. Unnes Law Jurnal. Vol. 4. No. 1. 2015.

Gaffar, Janedri M. "Peran Mahkamah Konstitusi dalam Perlindungan Hak Asasi Manusia”. Jurnal Konstitusi. Vol.10. No.1. Maret 2013.

Hamidi, Jazim dan Mustafa Lutfi. "Constitutional Question (Antara Realitas Politik dan Implementasi Hukumnya”. Jurnal Konstitusi. Vol. 7. No.1. Februari 2010.

MD, Moh. Mahfud. "Rambu Pembatas dan Perluasan Kewenangan Mahkamah Konstitusi”. Jurnal Hukum. Vol.16. No.4. 2009.

Muhtadi. "Penerapan Teori Hans Kelsen Dalam Tertib Hukum Indonesia”. Fiat Justitia Jurnal Ilmu Hukum. Vol. 5. September 2012.

Palguna, I Dewa. "Constitutional Queston: Latar Belakang dan Praktik di Negara Lain Serta Kemungkinan Penerapannya di Indonesia”. Jurnal Hukum. Vol. 17. No. 1. Januari 2010.

Passaglia, Paolo. "Making a Centralized System of Judicial Review Coexist with Decentralized Guardians of the Constitution: The Italian Way”. Italian Law Journal. Vol. 2. April 2016.
Qomar, Nurul. "Kewenangan Judicial Review Mahkamah Konstitusi”. Jurnal Konstitusi. Vol. 1. 2012.

Sagama, Suwardi. "Analisis Keadilan. Kepastian Hukum dan Kemanfaatan dalam Pengelolaan Lingkungan”. Mazahib. Vol. 15. No. 1. Juni 2016.

Satria, Josua C. Dan Pan Mohamad F. "Penambahan Kewenangan Constitutional Question di Mahkamah Konstitusi sebagai Upaya untuk Melindungi HakHak Konstitusional Warga Negara”. Jurnal Konstitusi. Vol. 15. No. 4. Desember 2018.

Subiyanto, Achmad Edi. "Perlindungan Hak Konstitusional Melalui Pengaduan Konstitusional”. Jurnal Konstitusi. Vo. 8. No. 5. Oktober 2011.

Sunarto. "Prinsip Check and Balances dalam Sistem Ketatanegaraan Indonesia”. Masalah-Masalah Hukum. Vol. 45. No.2. April 2016.

Susanto, Mei. "Kewenangan Mahkamah Konstitusi sebagai Negative Budgeter dalam Pengujian Undang-Undang Anggaran Pendapatan dan Belanja Negara”. Jurnal Konstitusi. Vol. 14. No. 4. Desember 2017.

Yulistyowati, Efi. Endah Pujiastuti. dan Tri Mulyani. "Penerapan Konsep Trias Politica dalam Sistem Pemerintahan Republik Indonesia: Studi Komparatif atas UndangUndang Dasar Tahun 1945 Sebelum dan Sesudah Amandemen”. Jurnal Dinamika Sosial Budaya. Vol. 18. No. 2. Desember 2016.

Zoelva, Hamdan. "Constitutional Complaint dan Constitutional Question dan Perlindungan Hak-Hak Konstitusional Warga Negara”. Jurnal Media Hukum. Vol. 19. No. 1. Juni 2012. 


\section{Buku}

Arifin, Firmansyah et.al..eds.. Hukum dan Kuasa

Konstitusi. Jakarta: Konsorsium Reformasi Hukum Nasional. 2004.

Arifin, Firmansyah dan Juliyus Wardi. ed.. Merambah Jalan Pembentukan Mahkamah Konstitusi di Indonesia. Jakarta: Konsorsium Reformasi Hukum Nasional. 2002.

Asshiddiqie, Jimly. Model-Model Pengujian Konstitusional di Berbagai Negara. Edisi Kedua. Cet. Pertama. Jakarta: Sinar Grafika. 2010.

Asshiddiqie, Jimly dan Ahmad Syahrizal.

Peradilan Konstitusi di 10 negara. Jakarta: Sinar Grafika. 2012.

Cappelleti, Mauro. The Judicial Process in Comparative Perspective. Oxford: Clarendon Press. 1989.

Harman, Benny K. Mempertimbangkan Mahkamah Konstitusi. Jakarta: Kepustakaan Populer Gramedia. 2013.

Hernoko, Agus Yudha. Hukum Perjanjian: Asas Proporsionalitas dalam Kontrak Komersial. Jakarta: Prenadamedia Group. 2014.

MD, Moh. Mahfud. et al.. Constitutional Question: Alternatif Baru Pencari Keadilan Konstitusional. Malang: Universitas Brawijaya Press. 2010.

Sardini, Nur Hidayat dan Gunawan Suswantoro (editor). 60 Tahun Jimly Asshiddiqie Menurut Para Sahabat. Jakarta: Yayasan Pustaka Obor Indonesia. 2016.

Yaqin, Arief Ainul. Constitutional Question Kewenangan yang Terlupakan dan Gagasan untuk Melembagakannya di Mahkamah Konstitusi. Jakarta: Sinar Grafika. 2018.

\section{Pustaka dari Majalah}

Safa'at, Muchamad Ali. "Menggagas Constitutional Question di Indonesia”. Majalah Konstitusi Berita Mahkamah Konstitusi. Desember 2009.

\section{Pustaka dalam Jaringan}

Mahkamah Konstitusi. "Rekapitulasi Perkara Pengujian Undang-undang”. https://mkri.id/ index.php?page $=$ web. RekapPUU\& menu=5 . diakses tanggal 24 Februari 2019.

\section{Putusan Pengadilan}

Putusan Mahkamah Konstitusi No. 013-022/ PUU-IV/2006.

\section{Makalah}

Widayati. "Rekonstruksi Kelembagaan MPR". Prosiding Seminar Nasional. Pengembangan Epistimologi Ilmu Hukum. Universitas Muhammadiyah Surakarta. April 2015. 